\title{
Why There Are Certain Parallels Between Joachim C. Fest's Hitler-Biography and Michael Wolff's Trump-Book
}

\author{
Christian Fuchs
}

\section{University of Westminster}

\begin{abstract}
Joachim C. Fest published one of the most widely read Hitler biographies in 1973. Are there parallels of its analytical approach to Michael Wolff's "Fire and Fury: Inside the Trump White House"?
\end{abstract}

Keywords: Donald Trump, Joachim C. Fest, Hitler, Michael Wolff, authoritarian capitalism

\section{Joachim C. Fest's Analysis of Hitler}

Demagogues, who are entangled into history's negative dialectics, attract a massive amount of public attention, including in the form of monographs. The Library of Congress, the world's largest library, lists in its catalogue around 3,300 books that have "Hitler" in its title. Joachim C. Fest's (1974) Hitler-biography, first published in German in 1973 and in English in 1974, is one of the most widely-read books about Nazi-Germany.

Fest portrays Hitler as having had a distorted psychological character: "The phenomenon of Hitler demonstrates, to an extent surpassing all previous experience, that historical greatness can be linked with paltriness on the part of the individual concerned. For considerable periods his personality seemed disintegrated, as if it had evaporated into unreality" (Fest 1974, 9). "There is surely a psychological link between this sense of being an outsider and the readiness to employ a whole nation as material for wild and expansive projects, even to the point of destroying the nation" (Fest 1974, 14). "Unlike the Fascist type in general, he was not seduced by history but by his own educational experience, the shudders of happiness and terror that had been his in puberty" (Fest 1974, 758). "Nervous weakness compensated for by superman poses: in this, too, Hitler revealed his link with the late-bourgeois age, with the period of Gobineau, Wagner, and Nietzsche" (Fest 1974, 759). "The purpose of all the ceremonies and mass celebrations was obviously to engage the popular imagination and rally the popular will into a unitary force. But beneath the surface it is possible to discern motives that throw light upon Hitler's personality and psychopathology" (Fest 1974, 517).

So Fest characterises Hitler in terms of "paltriness", "outsiderhood", "unreality", "shudders of happiness", "nervous weakness", and "psychopathology". He reduces the explanation of Nazi-fascism to Hitler as individual and to an alleged mental illness. Because Nazi-fascism is for Fest all about Hitler, it also disappeared in his explanation with Hitler's death: "Almost without transition, virtually from one moment to the next, Nazism vanished after the death of Hitler and the surrender". The repeated surges of neo-Nazism cannot be explained based on such an approach.

Also many other individuals experience difficult family situations and career disappointments, but such experiences do not regularly lead to the involvement in and planning of the systematic, industrial annihilation of six million Jews. Psychological 
explanations are insufficient and disregard the ideological and political-economic aspects of fascism. Consequently, Fest gives relatively little attention to the Shoah.

Ian Kershaw argues in his book Hitler, the Germans, and the Final Solution that Joachim C. Fest (1974) and Alan Bullock (1952) wrote in their Hitler-biographies little on "the persecution, the murder, of the Jews and on the war itself - both completely inextricable from the history of Nazism" (Kershaw 2008, 18). Hermann Graml in one of the first reviews of Fest's book criticised that "Fest with his method suppresses the large part that certain economic circles - and other conservative groups such as the army and churches - played in the collapse of the Weimar Republic and therefore at least indirectly in the rise of the Nazis"1 (Graml 1974, 88). Reinhard Kühnl in his book Faschismustheorien (Theories of Fascism) characterises the type of approach that Fest advances as explaining fascism from "the thought, will and actions of the fascist leader" ${ }^{2}$ (Kühnl 1990, 53) and ignoring that "the leader cannot lead without [...] an alliance with specific political forces and interests against others"3 (Kühnl 1990, 55).

\section{Michael Wolff's Analysis of Trump}

Trump is a far-right demagogue, but comparing him to Hitler or Nazi-fascism (see for example http://trumpandhitler.com) downplays the singularity of the Shoah. It is for certain that the phase of US politics under Trump will be particularly remembered in history. The possibility that this era will be remembered (in case remembering will still be possible) as starting a nuclear war cannot be ruled out, although it is more likely that South Korea and China will seek a diplomatic solution to the North Korea crisis because South Korea has no interest in being involved in a nuclear war and China does not want to see one in its backyard. History books about will certainly also involve chapters and passages about Trump's use of Twitter. The Trump era may end in disasters, in impeachment, after four years, or (more unlikely) after eight years. Only history will tell.

One year after Trump's presidency started, the first books about his political rise have been published. Michael Wolff's (2018) Fire and Fury: Inside the Trump White House has thus far attracted the widest public interest. Trump certainly does not like the book, which is why some of his tweets claim that it is "[f]ull of lies, misrepresentations" and that "Michael Wolff is a total loser who made up stories in order to sell this really boring and untruthful book".

Wolff's account is journalistic, not academic. But there are nonetheless parallels to Fest's approach. Wolff repeats Fest's mistake of individualising and psychologising far-right politics. Trump is characterised as being silly and psychologically unstable: Trump "didn't process information in any conventional sense - or, in a way, he didn't process it at all" (Wolff 2018, 113). "Some believed that for all practical purposes he was no more than semiliterate" (Wolff 2018, 113-114). "'He's not only crazy,' declared [Trump-friend] Tom Barrack to a friend, 'he's stupid"' (Wolff 2018, 233). "In truth, he was often neither fully aware of the nature of what he had said nor fully cognizant of why there should be such a passionate reaction to it" (Wolff 2018, 249). "Rex Tillerson [...] had called the president 'a fucking moron.' [...] For Steve Mnuchin and Reince Priebus, he was an 'idiot.' For Gary Cohn, he was 'dumb as shit.' For H. R. McMaster he was a 'dope.' The list went on” (Wolff 2018, 304).

\footnotetext{
${ }^{1}$ Translation from German.

${ }^{2}$ Translation from German.

${ }^{3}$ Translation from German.
} 
Wolff characterises Trump as a psychologically unstable tabula rasa that can be politically moulded into any direction. There would have been a battle between Steve Bannon on the one side and Ivanka Trump and Jared Kushner on the other side (whom Wolff considers not just to be married, but to also form a political unity that he refers to as "Jarvanka") about who had been better able to politically manipulate Trump. Bannon would have tried to create a far-right president, "Jarvanka" a centrist one. Trump's government "represented a deeply structural assault on liberal values [...] But from the start it also was apparent that the Trump administration could just as easily turn into a country club Republican or a Wall Street Democrat regime. Or just a constant effort to keep Donald Trump happy" (Wolff 2018, 177). "Bannon and his ilk had made him the monster he more and more seemed to be" (Wolff 2018, 243).

The parallel between Fest's and Wolff's approach is that both reduce far-right demagoguery to an individual's psyche and leave out the importance of ideology and political economy. Trump's ideology was militarist, nationalist, authoritarian, etc. before and during his presidential campaign and has remained so after it. He is not an ideologically isolated individual, but represents the far-right within the Republican Party that has been strengthened since the rise of the Tea Party movement in 2009. $\mathrm{He}$ is not a political tabula rasa, but represents the political economic project of trying to make the billionaire class faction identical with the ruling political elite.

\section{Digital Demagogue}

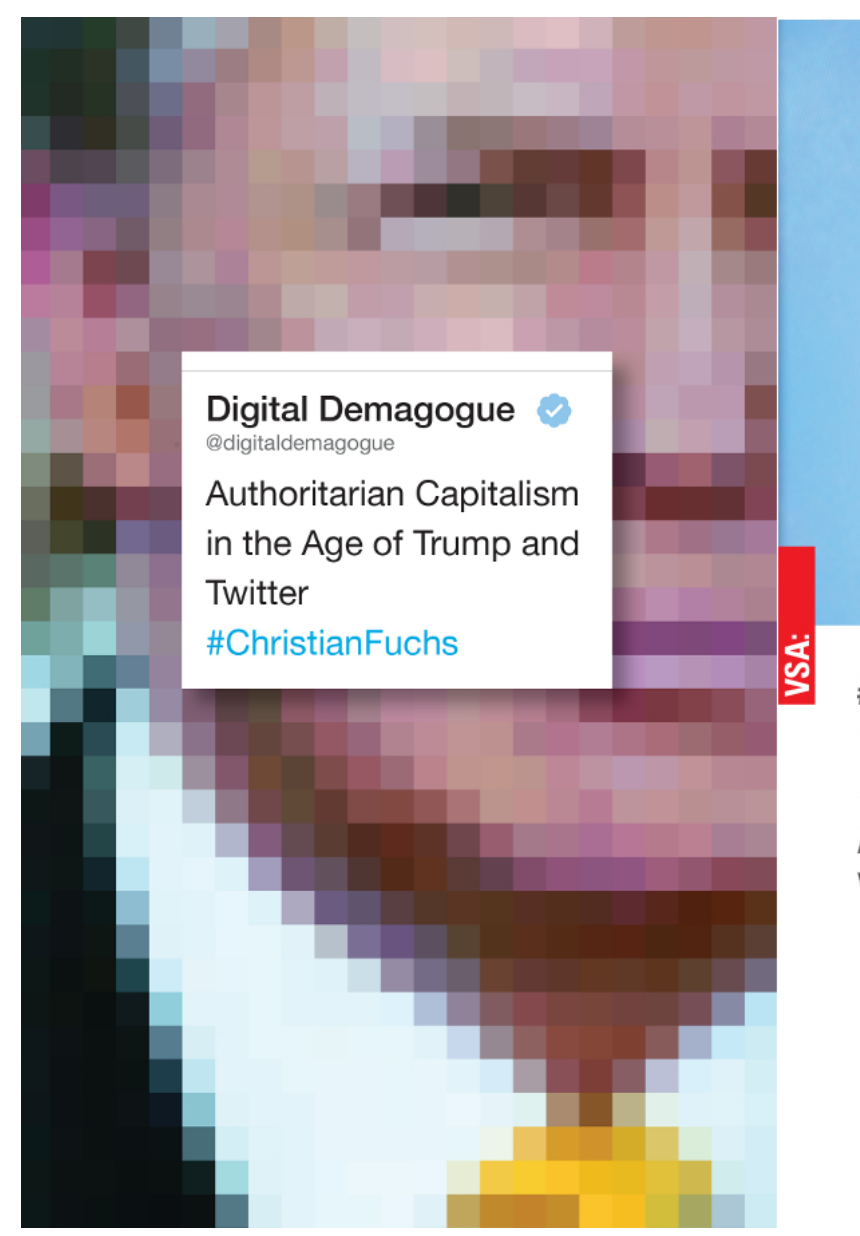

\#Christian Fuchs

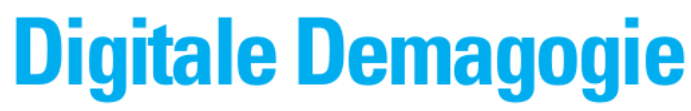

Autoritärer Kapitalismus in Zeiten von Trump und Twitter

The book Digital Demagogue: Authoritarian Capitalism in the Age of Trump and Twitter (Fuchs 2018) takes a completely different approach. It combines political econo- 
my, ideology critique and political psychology for explaining the emergence of authoritarian capitalism and its ideology, organisations, movements and individuals.

Digital Demagogue's analysis shows that Trump certainly has an authoritarian character structure. But such a character structure does not develop simply because of early childhood or teenage experiences or because of a psychological predisposition, but is embedded into the broader political economic formation and ideological formations that form structures of feelings and experience that shape socialisation over long periods of time. And given the social character of these structures, authoritarianism does not produce single authoritarian individuals, but authoritarian movements with leaders and followers who are all small leaders envisioning themselves as big leaders controlling political, economic and ideological power.

There is no automatic link between economic position and political consciousness. Voting, supporting or joining authoritarian movements is not just a matter of class structures and ideological efforts, but also has to do with the history of an individual's personal, economic, political and cultural socialisation that makes him or her more or less affectually prone to far-right propaganda. Right-wing authoritarianism often intensifies in and after political-economic crises, but also involves conscious ideological projects that try to speak to human's hopes, fears, desires, and aggressions.

Individualising psychological explanations, as advanced by both Fest and Wolff, fall short of explaining the causes and dynamics of right-wing authoritarianism. A theory of authoritarianism needs to combine political economy, ideology critique, and political psychology. As part of the analysis of the dialectic of object and subject it also needs to integrate structures and practices of communication, including the use of social media.

\section{References}

Bullock, Alan. 1952. Hitler: A Study in Tyranny. London: Odhams Press.

Fest, Joachim C. 1974. Hitler. Orlando, FL: Harcourt.

Fuchs, Christian. 2018. Digital Demagogue: Authoritarian Capitalism in the Age of Trump and Twitter. London: Pluto.

Graml, Hermann. 1974. Probleme einer Hitler-Biographie. Kritische Bemerkungen zu Joachim C. Fest. Vierteljahreshefte für Zeitgeschichte 22 (1): 76-92.

Kershaw, Ian. 2009. Hitler, the Germans, and the Final Solution. New Haven, CT: Yale University Press.

Kühnl, Reinhard. 1990. Faschismustheorien. Ein Leitfaden. Heilbronn: Distel Verlag. Updated edition

Wolff, Michael. 2018. Fire and Fury: Inside the Trump White House. London: Little, Brown.

\section{About the Author}

Christian Fuchs

is co-editor of tripleC: Communication, Capitalism \& Critique (http://www.triple-c.at). http://fuchs.uti.at 